\title{
ICHNOFOSSILS OF THE CAMPANO-MAASTRICHIAN GOMBE FORMATION FROM GONGOLA BASIN, UPPER BENUE TROUGH, NIGERIA: THEIR ENVIRONMENTAL SIGNIFICANCE
}

Kwaya, M.Y.

Department of Geology, Bayero University, P.M.B. 3011, Kano

Email: mkyerima.geo@buk.edu.ng

\begin{abstract}
The Campano-Maastrichtian Gombe Formation is located in the Gongola Basin of Upper Benue Trough and forms the north-south outcrop in western margin of the basin. The sediments were believed to have been deposited under conditions of deltaic, estuarine and shoreface environments. Ichnofossils or trace fossils some of localities within the Campano-Maastrichian Gombe Formation were studied with the aim of revisiting the paleoenvironmental significance and add to existing knowledge based. The study revealed two major types of ichnofacies, the Cruziana and Skolithos. Cruziana ichnofacies are the Thalassinoides and moderately common Planolites whilst the Skolithos ichnofacies elements are predominantly the Ophiomorpha's. However, the Ophiomorpha is a common trace fossil that is normally found in Mesozoic to Cenozoic sedimentary rocks deposited in either shallow or marginal marine environments. The Thalassinoides and Planolites ichnofossils may be found in both the marine and coastal facies of the Cretaceous sediments and this further suggest that the paleodepositional environment of the Campano-Maastrichian Gombe Formation as coastal and shallow marine deposited under higher and lower energy of the wave and tidal processes.
\end{abstract}

Keywords: Ichnofossils; Cruziana; Skolithos; Gombe Formation; Cretaceous

\section{INTRODUCTION}

Ichnology is a field of research on biogenic structures that are preserved on the bedding planes or within the beds which are produced by life activity of organisms (Nichols, 2009). The structures are called ichnofossils or trace fossils. Ichnologists can determine the ethology of trace fossils and distinguish ichnofacies and ichnocoenoses, though recognition of trace makers is commonly problematic. Ichnology is very useful in studies of palaeoecology, determination of bathymetry of sedimentary basins and other palaeoenvironmental parameters (see Walker and Plint, 1982; Nichols, 2009). In the Gongola Basin of the Northern Benue Trough, there is a great potential for ichnological studies because of the good exposure of sediments of different facies and ages.

Ichnologic research during the last century, with increasing intensity in the present one, led to the development of trace fossil analysis as a significant contributor to a wide range of fields, including palaeobiology, palaeoecology, biostratigraphy, palaeobathymetiry and sedimentology (Nagy et al. 2016). During the last decade, a rapid expansion of this approach has significantly contributed to basin analysis (including allostratigraphy, cyclostratigraphy, genetic stratigraphy, sequence stratigraphy). In sequence stratigraphy, trace fossil associations have been used to characterize discontinuity surfaces mainly based on the recognition of substrate-controlled ichnofacies. Moreover, vertical changes in ichnologic features across the sequences have been applied for characterizing parasequences, sets and system tracts.

The Campano-Maastrichtian sedimentary successions of Gombe Formation arelocated in the Gongola Basin of Northern or Upper Benue Trough (Fig. 1) and they forms a north-south outcrop in western margin of the basin with a width of about $15 \mathrm{~km}$ (Carter et al., 1963; Zarborski et al. 1997; Abubakar, 2006). Trace fossil assemblages from a variety of outcropping facies in the Gombe Formation of Gongola Basin were less studied. Nearly all previous studies are based on ichnofacies established for marine environments as there is no ichnofacies based on local conditions that can be applied to the coastal system. The present study investigated the major trace fossil assemblages that are associated with various coastal and shallow marine depositional systems of the CampanianMaastrichian sedimentary sequences of Gombe Formation in the Gongola Basin of the Upper Benue Trough. This is with the aim to present the major trace fossils so as to develop a framework that can assist with the interpretation 
BAJOPAS Volume 13 Number 1, June, 2020

of paleodepositional environments and future stratigraphical distribution studies.

\section{Geology}

The Benue Trough is a major NE - SW trending rift basin that extends for over $1000 \mathrm{~km}$ starting from the northern margin of the Niger Delta in the south to southern margin of the Chad Basin in the north (Fig. 1). It contains over $6000 \mathrm{~m}$ of Cretaceous - Tertiary sediments associated with Tertiary volcanics of which those pre-dating the mid-Santonian have been compressionally deformed, faulted and uplifted in several places (e.g. Nwajide, 2013; Guiraud, 1990; Guiraud and Maurin, 1992). The Benue Trough wasgeographically sub-divided into the lower, middle and upper benue portions (Fig. 1). The Upper Benue Trough is a $Y$ - shaped that is made up of three arms namely: the $E-W$ trendingYola Arm, N-S trending Gongola Arm and the NE-SW trendmain arm (Muri-Lau Arm) (Zarborski et al. 1997).

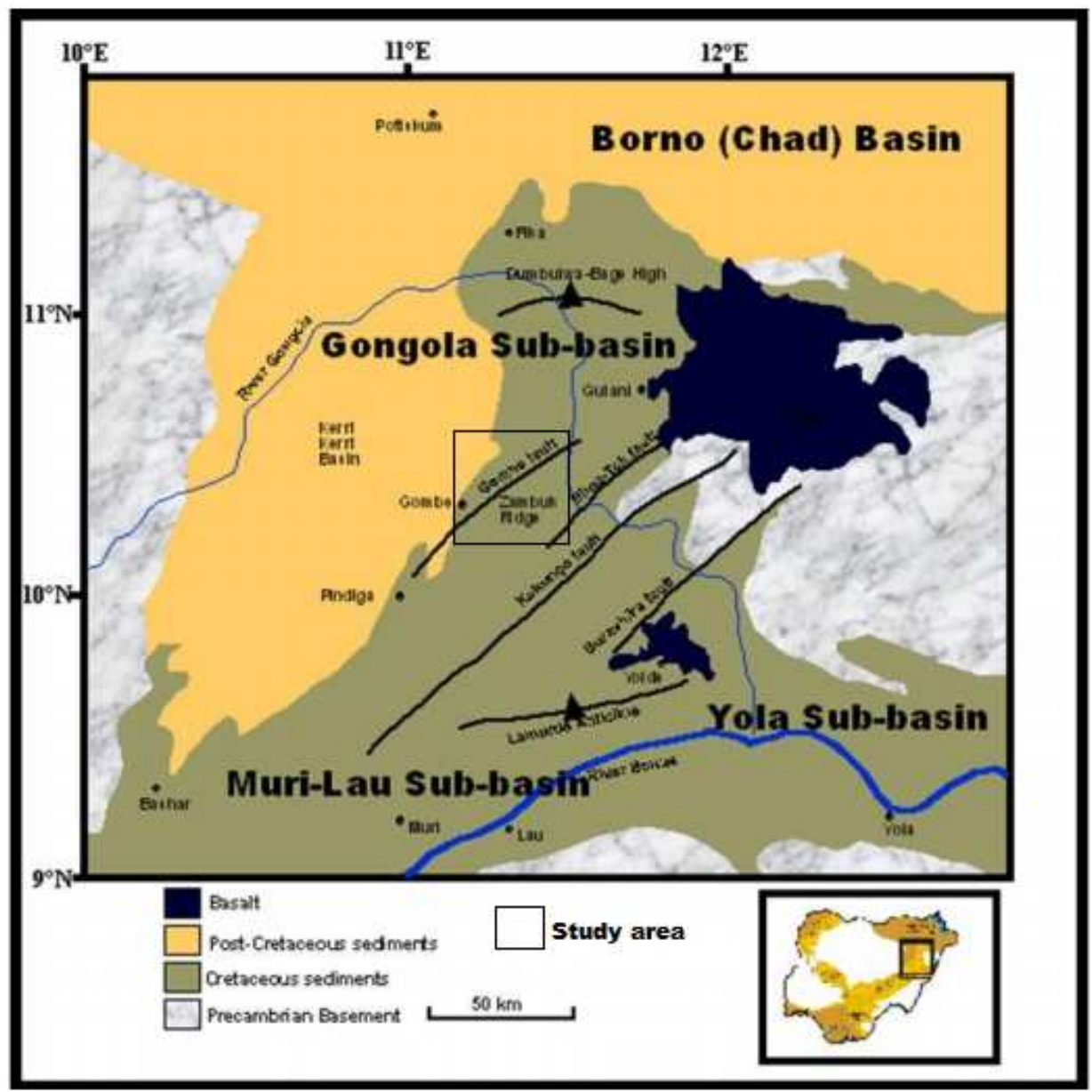

Figure 1: Geological map of the Northern Benue Trough showing the study area (modified from Zaborski et al., 1997)

The sedimentary sequence infilling of the Northern Benue Trough is made up of continental, transitional and marine deposits and they range from Aptian to Paleocene in age(Carter et al. 1963; Zaborski et al., 1997; Abubakar, 2014). The Bima Formation, a continental formation, represents the basal part of the sedimentary succession in all the three arms of the Northern Benue Trough shown in Figure 2. It unconformably overlies the Precambrian basement complex and consists of three siliciclastic members: the Lower Bima (B1), the Middle Bima (B2) and the Upper Bima (B3). Its lithology and depositional environments have been discussed by several authors (Carter et al., 1963;Guiraud, 1990). The Yolde Formation lies conformably on the Bima Formation in the whole of the Northern Benue Trough (Fig. 2). This formation is of Cenomanian age (Lawal andMaullade, 1986) and represents the beginning of marine incursion into this part of the Benue Trough. 


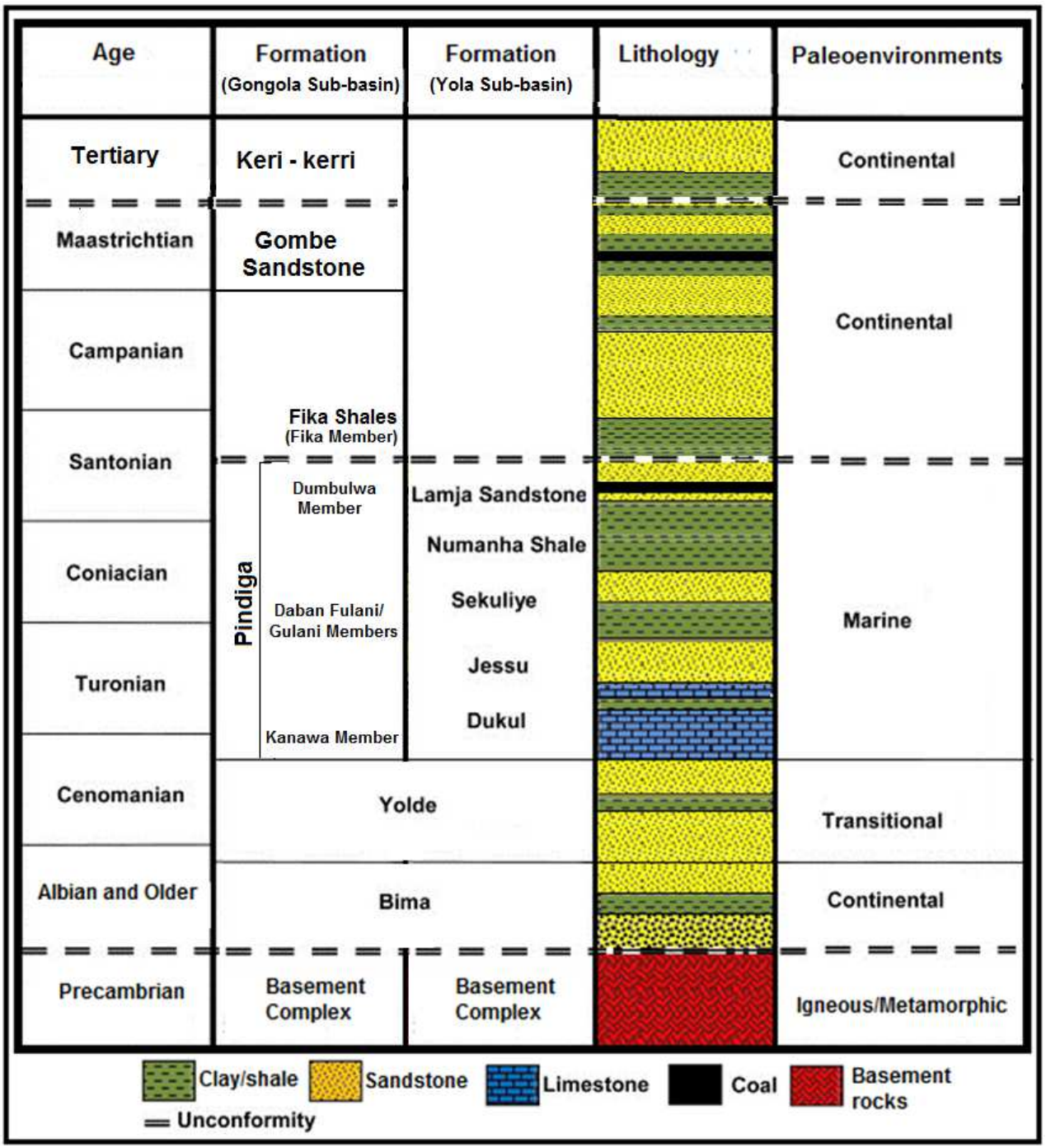

Figure 2: Stratigraphic succession of the Northern Benue Trough showing Yola and Gongola Sub-basins (After Sarki Yandoka et al. 2015)

The Yolde Formation was deposited in a barrier island/deltaic setting (Abubakar, 2006). In the Gongola Sub - basin (Arm), the Yolde Formation is conformably overlain by the Pindiga Formation which is lateral equivalent to Gongila Formation and Fika Shale (Carter et al., 1963), and they all represent a full marine incursion into the Gongola Arm (Figure 3). The estuarine/deltaic Gombe Formation of Maastrichtian age overlies the Pindiga Formation and it represents the youngest Cretaceous sediments in the Gongola Basin. The Paleocene Kerri-Kerri Formation unconformably overlies the Gombe Sandstone and represents the only recordof Tertiary sedimentation in the Gongola Basin.

\section{Field method}

Togographic maps as well as geological mapsof the study area were studied in detail and employed in the fieldwork for the current research. This is in order to identify the potential areas where Campano-Maastrichtian Gombe Formation is well exposed. Along the well exposed outcrops of Gombe Formation,trace or ichnofossils are carefully studied as presented in the next section.Outcrops were identified where trace fossils are well exposed. Field photographs were taken to show their lateral extent on the outcrops. Temporal and spatial distribution of the fossils was evaluated to determine the extent of their regional distribution and their relationships to paleodepositional environmental significance. The Campano-Maastrichian Gombe Formation host different types of ichnofossils; cruziana (e.g. ophiomorpha) and skolithos (e.g. thalassinoides and planolites). 
BAJOPAS Volume 13 Number 1, June, 2020

\section{RESULTS AND DISCUSSIONS}

The Campano-Maastrichian sediments of Gombe Formation were dominated by trace fossils that indicate coastal-shallow marine paleodepositional setting. The trace fossil assemblage are interpreted as the Cruziana ichnofossil with a component of the Skolithos ichnofossil. Cruziana ichnofacies elements include robust Thalassinoides and moderately common Planolites. Skolithos ichnofacies elements are Ophiomorpha occuring on saltysilty beds. Trace fossil assemblages based on this study are presented as follows:

\section{Skolithos ichnofossils}

The Skolithos Ichnofacies can be recognized by a low diversity of abundant vertical domichnia burrows (Skolithos, Diplocraterion and Arenicolites), fodinichnia (Ophiomorpha), and fugichnia (Dalrymple, 2010). Ophiomorpha is a common trace fossil in the Mesozoic and
Cenozoic sedimentary rocks deposited in shallow and marginal marine environments. In shallow water deposits, Ophiomorpha is mainly represented by 0 . nodosa, while in deep-sea sediments $O$. rudis is most typical type.Ophiomorpha is also a substrate-controlled ichnotaxon, found mainly in fine- to mediumgrained sand deposits (e.g. Nichols, 2009). The ophiomorpha ichnofossils recognized in the Gombe Formation are assigned to the Ophiomorpha's found in coastal settings(see Fig. 3) owing to their general shape and the presence of more or less distinct pelletal lining of the burrow walls (Frey, 1975; Frey et al., 1985). On their species level, the ophiomorpha's are provisionally designated by open nomenclature. The weathered surface and the surrounding sandstone are coloured red to brown by iron oxide-hydroxide (Herold, 1934; Nagy et al. 2016).

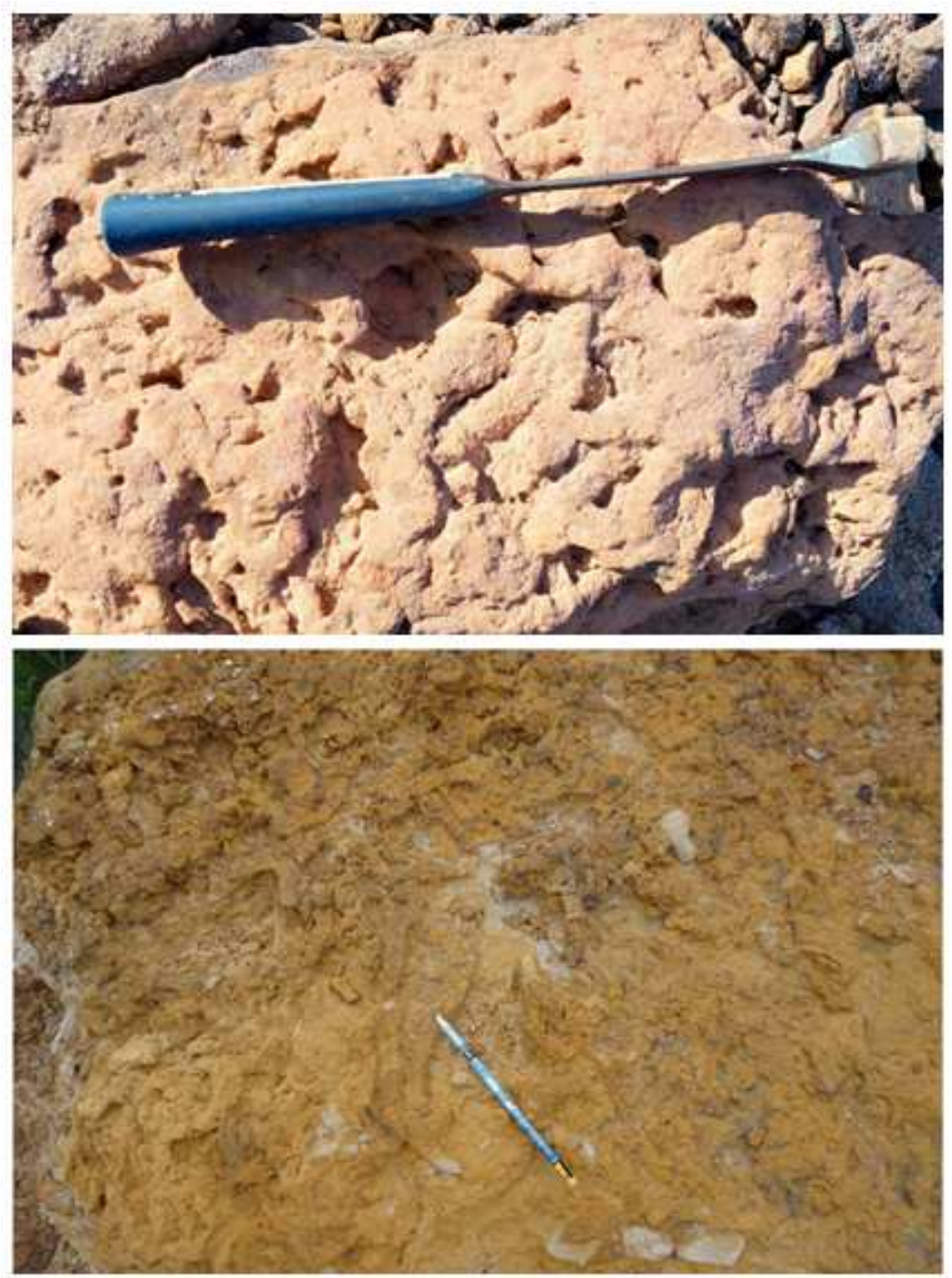

Figure 3: Ophiomorpha and thalassionoides ichnofossils of Gombe Formation 
BAJOPAS Volume 13 Number 1, June, 2020

\section{Cruziana ichnofossils}

The Cruziana Ichnofacies shows rich trace fossil diversity, with horizontal repichnia and vertical burrows.This ichnofacies represents continental shelf situations, below normal wave base, but may be affected by storm activity (e.g. Smith and Hasiotis, 2008). Thalassinoides and some Planolites are found in Campano-Maastrichian sediments of Gombe Formation (Figs. 4 and 5). Thalassinoides which are attributed to the group of dwelling structures, occur in all the marine and coastal facies in the Cretaceous.These organisms formed a system of hollow tunnels in the middle well ventilated ichnotier. In sandy sediments, the Thalassinoides burrows are rarely crossed by other bioturbations (Weimer and Hoyt, 1964). The burrows are confined to coarse-grained terrigenous, carbonate, and mixed sediments and contain assemblages of ichnofossils indicating coastal and shallow-water marine Skolithos and Cruziana ichnofacies. In the Mesozoic-Cenozoic, the producers of the Thalassinoides burrows were decapods, confirmed by finds of Hoploparia in them.
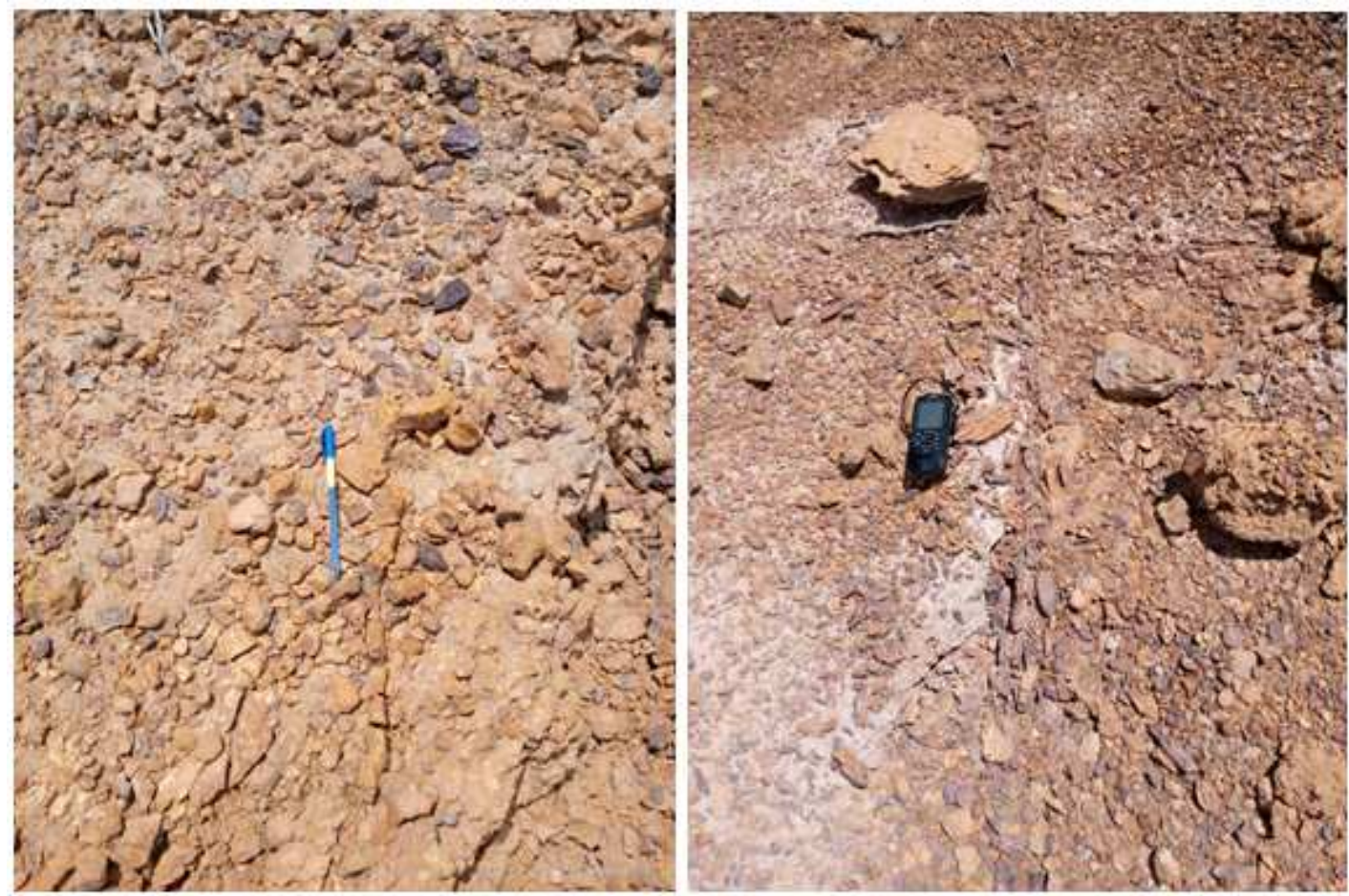

Figure 4: Thalassinoides ichnofossil of the Gombe Formation

\section{Environmental significance}

Trace fossil assemblages of some sections of Campano-Maastrichian Gombe Formation show dominance of Skolithos and Cruziana ichnofacies. However, trace fossils in tidedominated environments have a Cruziana ichnofacies, although higher energy tidal channels have a distal Skolithos ichnofacies. Tidal sand flats tend tohave more diverse and abundant traces than tidal channels (Howard and Frey, 1984). Trace fossils are more abundant in tidal mud flat facies than in tidal channels and sand flats, and whilst mud flat assemblages are more diverse than tidal channel assemblages, they are less diverse than sand flat assemblages.

Generally, these assemblages are similar to those in equivalent depositional environments in higher tidal range settings.Wave-dominated environments also have Cruziana assemblages, except for the upper shoreface that has a distal Skolithos assemblage (Beynon and Pemberton, 1992). Lower shoreface assemblages are more abundant and diverse than upper shoreface and belong to the proximal Cruziana ichnofacies. Trace fossils are more abundant and diverse in offshore transition facies than in either the upper or lower shoreface and belong to the distal Cruziana ichnofacies; assemblages in interbedded storm sands often include a minor component of the Skolithos ichnofacies (Pemberton and Frey, 1985). These assemblages are comparable to those from wave-dominated deposits from higher energy settings, except for the upper shoreface environment which contains a lower energy assemblage. 
BAJOPAS Volume 13 Number 1, June, 2020

The Gombe Formation composed of shoreface, estuarine and deltaic sequences defined by thick claystone facies of the pro-delta clays at base, passing upwards to interbedded sandstone and claystone facies of the delta slope and capped by thick sandstone facies of the delta front sands (Dike and Onumara, 1999). The delta front sands appear to be laterally discontinuous zones of laminations trending at high angle to the bedding which are either widespread across the bed or across several beds and they range in size in the order of tens of centimeters.Trace fossil assemblages in the Gombe Formation are comparableto those from higher energy settings except for shoreface which have a lower energy assemblage.Thus, there are no signifiant differences between the trace fossil assemblages and those from tide-dominated environments in higher tidal range settings. This is supported based on positions of major ichnofossils within the marine setting (Fig. 5) as suggested by Benton and Harper, (1997).

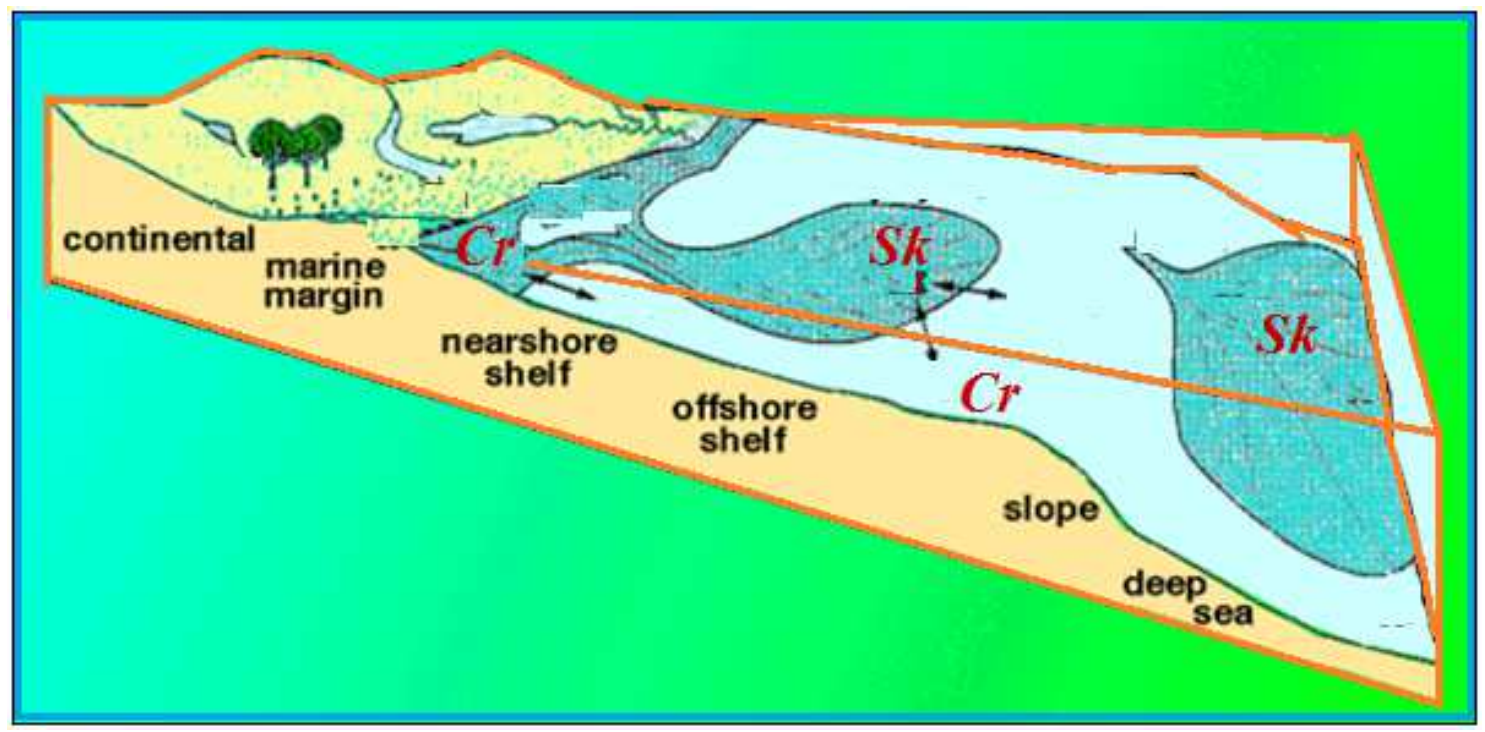

Figure 5: Typical position of major ichnofacies in marine and continental environments: Cr-Cruziana; Sk Skolithos (after Benton \& Harper, 1997)

\section{CONCLUSION}

Ichnofossils of the Campano-Maastrichian Gombe Formation in the Gongola Basin, Upper Benue Trough were studied. The study revealed two major types of ichnofacies, the Cruziana and Skolithos. The trace fossil assemblage of the Cruziana ichnofossil have a component of the Skolithos ichnofossil. Cruziana ichnofacies are the Thalassinoides and moderately common Planolites while Skolithos ichnofacies elements are predominantly Ophiomorpha.Ophiomorpha is

\section{REFERENCES}

Abubakar, M.B., (2006). Biostratigraphy, palaeoenvironments and organic geochemistry of the Cretaceous sequences of the Gongola Basin, Upper Benue Trough, PhD unpublished thesis, Abubakar Tafawa Balewa University Bauchi, Nigeria pp. 315.

Abubakar, M.B., (2014). Petroleum Potentials of the Nigerian Benue Trough and Anambra Basin: A Regional Synthesis. Natural Resources, 5(1), 25-58. a common trace fossil in the Mesozoic and Cenozoic sedimentary rocks deposited in shallow and marginal marine environments. Meanwhile, Thalassinoides and Planolites occur in both the marine and coastal facies of the Cretaceous sediments. This confirm the paleodepositional environment of Campano-Maastrichian Gombe Formation as coastal and shallow marine under higher and lower energy of wave and tidal processes.

Benton, M.J., and Harper, D.A.T., (1997). Basic Paleontology. Xv +342pp.

Beynon, B. M. and Pemberton, S. G., 1992. Ichnological signatureof a brackish water deposits: an example from the Lower Cretaceous Grand Rapids Lower Formation, Cold Lake Oil Sands area, Alberta. In: Pemberton, S. G. (Ed.), A Core Workshop: Applications of Ichnology to Petroleum Exploration. SEPM Core Workshop No. 17, 199 - 221.

Carter, J.D., Barber, W., Tait, E.A., Jones, G.P., (1963). The geology of parts of the 
BAJOPAS Volume 13 Number 1, June, 2020 Adamawa, Bauchi and Bornu Provinces in Northeastern Nigeria. Geological Survey Nigerian Bulletin 30, 53-61.

Frey, Robert w. (1975), The Study of Trace Fossils: Springer-Verlag, New York, 562 p.

Frey, Robert W. and Howard, James D. (1985), Upper Cretaceous Trace Fossils, Book Cliffs of Utah: A Field Guide, in Depostional Facies of the Castlegate and Blackhawk Formations, Book Cliffs, Eastern Utah: Field Trip No. 10, Rock Mountain Section SEPM (Society for Sedimentary Geology), p. 115-152.

Guiraud, M., (1990). Tectono-sedimentary frameworks of the Early Cretaceous continental Bima Formation (Upper Benue Trough, NE Nigeria). Journal of African Earth Sciences 10, 341 -353.

Guiraud, R., Maurin, J.E., (1992). Early Cretaceous rifts of Western and Central Africa: an overview, in: P.A., Ziegler, (Eds.), Geodynamics of Rifting, Volume II. Case History Studies on Rifts: North and South America and Africa. Tectonophysics, 213, 153-168.

Herold, C. Lathrop (1934), Fossil markings in the Carmelo Series (Upper Cretaceous), Point Lobos, California, Journal of Geology, v. 42, p. 630-640.

Howard, J. D. and Frey, R.W., 1984. Characteristic trace fossils in nearshore to offshore sequences, Upper Cretaceous of eastcentral Utah. Can. J. Earth Sci., 21, $200-219$

Hill, G.W. (1981), Ichnoenoses of a Paleocene submarine canyon floor, Point Lobos, California, in (Frizzel, V., ed.) Upper Cretaceous and Paelocene turbidites, central California Coast: Pacific Section, Society of Economic Paleontologists and Mineralogists, Guide Book to Field Trip No. 6, p. 93-104.

Nagy, J., Francisco J., Tovar, R., Reolid, M. (2016). Environmental significance of Ophiomorpha in a transgressiveregressive sequence of the Spitsbergen Paleocene. Polar Research, DOI: https://dol.org/10.3402/polar.v35.24192
Nichols, G.J., (2009). Sedimentology and Stratigraphy, John Wiley and Sons, New York, pp. 452

Nwajide C.S., (2013). Geology of Nigeria's Sedimentary Basins.CSS Bookshops Ltd., Lagos, Nigeria, 565 pp.

Pemberton, S. G. and Frey, R. W., 1985. The Glossifungites ichnofacies: modem examples from the Georgia coast, U.S.A. In: Curran, H. A. (ed.), Biogenic Structures: Their Use in Interpreting Depositional Environments. SEPM Spec. Pub. 35, 237-259.

Sarki Yandoka, B.M., Abdullah, W.H., Abubakar, M.B., Hakimi, M.H., Mustapha, K.A., Adegoke, K.A., (2015). Organic geochemical characteristics of Cretaceous Lamja Formation from Yola Sub-basin, Northern Benue Trough, NE Nigeria: implication for hydrocarbongenerating potential and paleodepositional setting. Arabian Journal of Geosciences, DOI 10.1007/s12517-014-1713-3.

Smith, J.J. and Hasiotis, S.T. (2008), Traces and burrowing behaviors of the cicada nymph Cicadetta calliope: Neoichnology and paleoecological significance of extant soil-dwelling insects, PALAIOS, v. 23, n. 8, p. 503-513.

Walker, R., Plint, A.G., (1992). Chapter 12: Wave- and storm-dominated shallow Marine systems. Facies models, response to sea level change. R. J. Walker, N. P. Ontario, Canada. In: Walker, R., James, N. (Eds.), Facies Models, Response to Sea Level Change, pp. 219-238.

Weimer, R.J. and Hoyt, H.H. (1964), Burrows of Callianassa major Say geologic indicators of littoral and shallow neritic environments, Journal of Paleontology, v. 38, p. 761-767.

Zarboski, P.F., Ugodulunwa, A., Idornigie, P., Nnabo, K., Ibe, (1997). Stratigraphy and structure of the Cretaceous Gongola Basin, Northeast Nigeria. Bulletin des Centres Research Exploration and Production Elf Aquataine 21(1), 154185. 